\title{
PENGARUH KEPEMIPINAN, MOTIVASI DAN KEDISPLINAN TERHADAP KOMITMEN ORGANISASI DAN DAMPAKNYA TERHADAP KINERJA PEGAWAI PADA DINAS PERTANIAN KABUPATEN PIDIE
}

\author{
Cut Italina, Afridar, Ratna \\ PPIM Universitas Malikussaleh, Lhokseumawe
}

\begin{abstract}
This study tested the influence of workload, quality of work life and work motivation against the performance of the employees, as well as testing the effect of mediation from the variable job satisfaction. The sample in this research are 114 employees remain Civil Records residence and Office of Lhokseumawe, North Aceh Regency. Analysis tool used is the analysis of the path (path analysis) with the SEM methods (structural equation modelling) using Amos. The results showed that each variable workloads, quality of working life is a positive and significant effect against the working motivation and work performance and motivation variables mediate the work load with variable performance partially mediation and work motivation variables mediate the quality of working life with full performance variables of mediation.
\end{abstract}

Keywords: workload, quality of working life, Employment, Motivation and performance of Employees

\section{PENDAHULUAN}

Manajemen Sumber Daya Manusia (MSDM) merupakan bagian dari manajemen keorganisasian yang memfokuskan diri pada unsur sumber daya manusia. Tugas MSDM adalah mengelola unsur manusia secara baik agar diperoleh tenaga kerja yang puas akan pekerjaannya. Di dalam organisasi, manusia merupakan salah satu unsur yang terpenting di dalam suatu organisasi. Tanpa peran manusia meskipun berbagai faktor yang dibutuhkan itu telah tersedia, organisasi tidak akan berjalan. Manusia merupakan penggerak dan penentu jalannya suatu organisasi, oleh karena itu hendaknya organisasi memberikan arahan yang positif demi tercapainya tujuan organisasi.

Keberhasilan suatu organisasi sangat ditentukan oleh kemampuannya mentransformasikan diri sesuai tuntutan perubahan dan memperkuat budaya yang mendukung tujuan organisasi. Organisasi memasuki era perbaikan secara terus menerus yang kelangsungan hidupnya ditentukan oleh kemampuan organisasi mengembangkan potensi sumber daya manusianya. Semakin disadari bahwa pegawai menjadi sumber daya yang terpenting dalam organisasi, kinerja pegawai sangat menentukan keberhasilan organisasi secara keseluruhan. Tanpa pegawai yang berkinerja tinggi, organisasi akan gagal mencapai tujuannya. 
Keberhasilan suatu organisasi dipengaruhi oleh kinerja individu pegawainya, suatu organisasi akan berupaya untuk meningkatkan kinerja pegawainya dengan harapan tujuan perusahaan dapat tercapai. Kinerja pada dasarnya adalah apa yang dilakukan atau tidak dilakukan pegawai.

Menurut Riva'i (2009), kinerja merupakan hasil atau tingkat keberhasilan seseorang secara keseluruhan selama periode tertentu dalam melaksanakan tugas dibandingkan dengan berbagai kemungkinan standar hasil kerja, target atau sasaran atau kriteria yang ditentukan terlebih dahulu dan telah disepakati bersama Sedangkan menurut Mangkunegara (2012), kinerja pegawai merupakan hasil kerja secara kualitas dan kuantitas yang tercapai oleh seseorang pegawai dalam melaksanakan tugasnya sesuai tanggungjawab yang diberikan kepadanya. Dengan demikian, kinerja merupakan hal yang penting bagi organisasi atau perusahaan serta dari pihak pegawai itu sendiri, oleh karena itu kinerja pegawai akan berjalan dengan efektif apabila didukung dengan kepemimpinan, motivasi, kedisplinan dan komitmen organisasi.

Menurut Riva’i (2009), kepemimpinan merupakan kemampuan dan keterampilan seseorang atau individu yang menduduki jabatan sebagai pimpinan satuan kerja, untuk mempengaruhi perilaku orang lain terutama bawahannya, untuk berfikir dan bertindak sedemikian rupa, sehingga melalui perilaku yang positif tersebut dapat memberikan sumbangsih nyata dalam pencapaian tujuan organisasi. Dalam organisasi ada dua pihak yang saling tergantung dan merupakan unsur utama dalam organisasi yaitu pemimpin sebagai atasan, dan pegawai sebagai bawahan. Kepemimpinan dalam suatu organisasi dirasa sangat penting, karena pemimpin memiliki peranan yang strategis dalam mencapai tujuan organisasi yang biasa tertuang dalam visi dan misi organisasi (Siagian, 2011).

Pemberian motivasi juga sangat penting dalam setiap perusahaan. Pegawai yang mempunyai motivasi kerja yang tinggi akan dapat mendorong pegawai tersebut bekerja lebih semangat serta dapat memberikan kontribusi positif terhadap pekerjaan yang telah menjadi tanggungjawabnya. Menurut Hasibuan (2007), motivasi kerja merupakan sesuatu yang menimbulkan dorongan atau semangat kerja atau dengan kata lain pendorong semangat kerja. Tanpa motivasi, seorang pegawai tidak dapat memenuhi pekerjaannya sesuai standar atau melampui standar karena apa yang menjadi motivasi dalam bekerja tidak terpenuhi. Sekalipun seorang karyawan pegawai yang memiliki kemampuan dalam bekerja tinggi tetapi tidak memiliki motivasi untuk menyelesaikan tugasnya maka hasil akhir dalam pekerjaannya tidak akan memuaskan. Untuk menciptakan kinerja pegawai agar berjalan dengan efektif, hal tersebut tidak hanya didorong dengan adanya motivasi saja tetapi dengan mempunyai disiplin kerja yang tinggi.

Menurut Sulistiyani dan Rosidah (2011), kedisiplinan merupakan prosedur yang mengoreksi atau menghukum bawahan karena melanggar peraturan atau prosedur. Disiplin merupakan bentuk pengendalian diri pegawai dan pelaksanaan yang teratur dan menunjukan tingkat kesungguhan tim kerja di dalam sebuah organisasi. Pendisiplinan pegawai adalah suatu bentuk pelatihan yang berusaha memperbaiki dan membentuk pengetahuan, sikap dan perilaku pegawai sehingga para pegawai dapat bekerja secara kooperatif dengan pegawai yang lain serta meningkatkan prestasi kerjanya (Siagian, 2010). Dengan pegawai mematuhi peraturan yang telah ditetapkan oleh perusahaan dan mempunyai 
disiplin yang tinggi maka akan menciptakan suasana perusahaan lebih kondusif sehingga akan berdampak positif pada aktivitas perusahaan, oleh karena itu setiap instansi mempunyai harapan agar pegawai dapat mematuhi peraturan yang telah ditetapkan.

Selain kepemimpinan motivasi dan kedisplinan hal lain yang perlu diperhatikan dalam organisasi adalah komitmen organisasi. Komitmen dalam organisasi mampu mendorong pegawai memberikan hasil yang terbaik bagi organisasi. Menurut Hasibuan (2012), komitmen organisasi merupakan sifat hubungan antara individu dengan organisasi kerja, dimana individu mempunyai keyakinan diri terhadap nilai-nilai dan tujuan organisasi kerja, adanya kerelaan untuk menggunakan usahanya secara sungguh-sungguh demi kepentingan organisasi kerja serta mempunyai keinginan yang kuat untuk tetap menjadi bagian dari organisasi kerja. Dalam hal ini individu mengidentifikasikan dirinya pada suatu organisasi tertentu tempat individu bekerja dan berharap untuk menjadi anggota organisasi kerja guna turut merealisasikan tujuan-tujuan organisasi kerja (Kuntjoro, 2009).

Fenomena yang terjadi saat ini, Kantor Dinas Pertanian Kabupaten Pidie diketahui merupakan Institusi Pemerintah yang bertugas melayani masyarakat, petani, kelompok tani, dan pengusaha dalam bidang pertanian dan kehutanan. Tujuan dari Dinas Pertanian Kabupaten Pidie untuk mewujudkan pembangunan yang telah ditetapkan setiap instansi pemerintah harus mempunyai misi dan visi yang jelas. Dalam suatu instansi seringkali hanya menuntut kinerja yang tinggi pada para pegawai, tanpa melihat faktor-faktor yang mempengaruhi. Padahal faktor mendasar dalam menunjang kinerja seperti kepemimpinan, motivasi, kedisplinan dan komitmen orgniasasi didalam perusahaan harus diperhatikan juga demi meningkatnya prodiktivitas pegawai. Di era globalisasi saat ini peningkatan pelayanan dan tuntutan masyarakat merupakan suatu kondisi yang tidak dapat dihindarkan, ini jelas menuntut adanya profesionalisme di dalam birokrasi. Pegawai Dinas Pertanian Kabupaten Pidie sebagai aparatur negara harus kreatif menciptakan inovasi, sehingga pekerjaan menjadi lebih efektif dan efisien, dalam hal ini seorang pemimpin instansi perlu untuk meningkatkan motivasi, kedisplinan dan komitmen organisasi, agar tujuan dari instansi dapat tercapai dan akan berdampak pada peningkatan produktivitas pegawai.

Berdasarkan pengamatan awal yang dilakukan peneliti, permasalahan yang terjadi di Dinas Pertanian Kabupaten Pidie, kepemimpinan, motivasi, kedisplinan dan komitmen organisasi dalam organisasi masih sangat kurang. Hal ini dapat dibuktikan dengan melihat keadaan langsung di Dinas Pertanian Kabupaten Pidie. Dilihat dari kepemimpinan di Dinas Pertanian Kabupaten Pidie, pemimpin tidak memahami situasi saat pegawai sedang bekerja, tidak pernah memberikan penghargaan terhadap pegawai yang berprestasi dalam bekerja, pemimpin tidak memiliki kreativitas dalam memimpin, tidak mampu menciptakan kedisiplinan terhadap pegawainya dan tidak pernah memberikan bimbingan khusus terhadap pegawai yang bekerja di Dinas Pertanian Kabupaten Pidie.

Dilihat dari motivasi yang diberikan di Dinas Pertanian Kabupaten Pidie, pegawai tidak memiliki kesungguhan dalam bekerja, tidak adanya rasa memiliki tanggung jawab dalam menyelesaikan tugas, tidak adanya keinginan untuk meningkatkan profesi yang baik dalam organisasi, kurangnya ketabahan dalam menghadapi tekanan saat bekerja dan selalu memiliki kekhawatiran akan kegagalan dalam menyelesaikan tugas. 
Dilihat dari kedisplinan, pegawai banyak yang tidak memahami tujuan saat bekerja dan tidak adanya kemampuan dalam menyelesaikan tugasnya, tidak memiliki keteladanan baik sesama pegawai maupun dengan masyarakat yang mendatangi kantor Dinas Pertanian Kabupaten Pidie, tidak adanya rasa ingin balas jasa terhadap pimpinannya, tidak menerima keadilan yang sama dengan pegawai lainnya di dalam organisasi, kurangnya waskat (pengawasan melekat) didalam organisasi, pegawai selalu menerima sanksi hukum terhadap pegawai yang telah melakukan kesalahan dan semua pegawai di Dinas Pertanian Kabupaten Pidie juga menerima ketegasan dari pemimpin agar menyelesaikan tugasnya dengan baik sehingga membuat pegawai tertekan saat bertugas sehingga menimbulkan kinerja pegawai semakin buruk.

Dilihat dari komitmen organisasi pada Dinas Pertanian Kabupaten Pidie, pemimpin tidak loyal dalam memberikan kepercayaan kepada pegawai yang bekerja, kurangnya kepedulian yang didapat dari pemimpin, tidak adanya rasa gembira dalam menyelesaikan tugas, pegawai merasakan pemimpin tidak memiliki kebanggaaan kepada pegawai yang telah menyelesaikan tugasnya dengan baik, pegawai selalu menerima kepercayaan yang diberikan oleh pimpinannya, hilangnya kesetiaannya pegawai di Dinas Pertanian Kabupaten Pidie dan ada beberapa pegawai mengurus untuk berpindah ke dinas lainnya dan organisasi selama ini kurang memberikan inspirasi kepada pegawainya.

Akibat kurangnya kepemimpinan, motivasi, kedisplinan dan komitmen organisasi pada Dinas Pertanian Kabupaten Pidie, kinerja pegawai semakin lama semakin menurun sehingga perlu di tingkatkan kembali agar organisasi menjadi lebih baik, kurangnya kinerja pegawai dilihat karena pegawai tidak memiliki kualitas dan kuantitas saat bekerja, banyak pegawai yang menyelesaikan tugasnya tepat waktu sesuai yang harapkan pemimpin, tidak adanya efektivitas pegawai saat menyelesaikan tugasnya sehingga membuat banyak pekerjaan yang tidak mencapai target penyelesaiannya, kurangnya kemandirian pegawai itu sendiri dan pegawai di Dinas Pertanian Kabupaten Pidie tidak memiliki komitmen saat bertugas.

\section{TINJAUAN PUSTAKA \\ KINERJA}

Kinerja adalah tingkat prestasi seseorang dalam suatu organisasi atau perusahaan yang dapat meningkatkan produktifitas. (Timpe, 2002)

Menurut Benardin (2007) variabel kinerja terdiri dari 6 indikator yaitu: 1) Kualitas,2) Kuantitas, 3) Ketepatan Waktu, 4) Efektivitas, 5) Kemandirian, 6) Komitmen.

\section{KOMITMEN ORGANISASI}

Komitmen Organisasi adalah suatu keadaan dimana seorang individu memihak organisasi serta tujuan-tujuan dan keinginan yang mempertahankan keanggotaannya dalam organisasi. (Timpe, 2002).

Variabel komitmen organisasi menurut Moydays, steers dan Porter (dalam Mas'ud 2004) terdiri dari 7 indikator yaitu: 1) Kualitas, 2) Kuantitas, 3) Ketepatan Waktu, 4) Efektivitas, 5) Kemandirian, 6) Komitmen, 7) Organisasi memberi inspirasi (KO7). 


\section{KEPEMIMPINAN}

Kepemimpinan merupakan suatu sikap yang dimiliki oleh pemimpin agar dapat mempengaruhi serta mengarahkan karyawan untuk dapat bekerjasama melaksanakan kegiatan tertentu untuk mencapai tujuan organisasi/perusahaan (Blanchard, 2012).

Menurut Hersey dan Blanchard, (2012) ada 5 indikator dari variabel beban kerja yaitu: 1 . Kejelasan dalam membaca situasi, 2.Pemberian penghargaan, 3.Kreativitas kepemimpinan dan 4.Menciptakan disiplin dan 5. Memberikan bimbingan.

\section{MOTIVASI}

Motivasi adalah keinginan atau kebutuhan yang melatarbelakangi seseorang sehingga ia terdorong untuk bekerja (Usman, 2006).

Menurut Suwanto dan Pransia (2011) terdiri dari 5 indikator yaitu: 1). Kesungguhan, 2) Rasa tanggung jawab, 3) Kebutuhan akan prestasi kerja yang baik, 4) Ketabahan dalam kerja, 5) Kekhawatiran akan kegagalan.

\section{KEDISIPLINAN}

Kedisiplinan adalah kesadaran dan kesediaan seseorang menaati semua peraturan perusahaan dan norma-norma sosial yang berlaku (Fathoni, 2006).

Menurut Hasibuan (2005) terdiri dari 8 indikator yaitu: 1) Tujuan dan kemampuan, 2) Teladan pimpinan, 3) Balas jasa, 4) Keadilan, 5) Waskat, 6) Sanksi hukum, 7) Ketegasan, 8) Hubungan kemanusiaan.

\section{KERANGKA KONSEPTUAL}

Kerangka konseptual adalah penjelasan keterkaitan atau hubungan suatu teori dengan faktorfaktor penting yang telah diketahui dalam suatu masalah tertentu. Kerangka koseptual dalam penelitian ini dibangun atas dasar pandangan ahli secara teoritis dan hasil penelitian secara empiris tentang hubungan kepemimpinan , motivasi, kedisiplinan dengan motivasi kerja maupun dengan kinerja, dan hubungan antara motivasi kerja dan kinerja.

Berdasarkan uraian di atas, maka dapat digambarkan kerangka konsep sebagai berikut: 


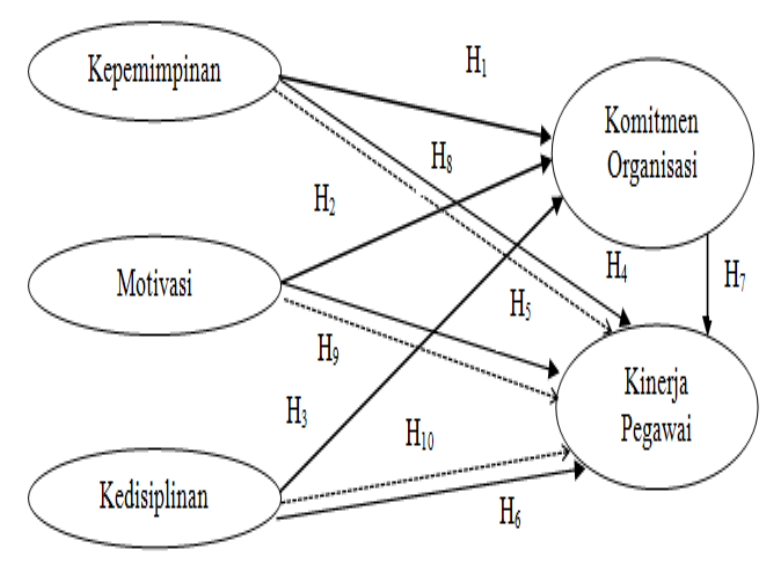

Gambar 1 Kerangka Konsep

\section{HIPOTESIS PENELITIAN}

Berdasarkan kerangka konsep penelitian, maka dapat dirumuskan 7 (tujuh) pernyataan hipotesis sebagai berikut:

H1: Kepemimpinan berpengaruh positif terhadap komitmen organisani Pada Dinas Pertanian Kabupaten Pidie.

H2: Motivasi berpengaruh positif terhadap komitmen organisani pada Dinas Pertanian Kabupaten Pidie.

H3: Kedisiplinan berpengaruh positif terhadap komitmen organisani pada Dinas Pertanian Pidie

H4: Kepemimpinan berpengaruh positif terhadap kinerja pegawai pada Dinas Pertanian Kabupaten Pidie.

H5: Motivasi berpengaruh positif terhadap kinerja pegawai Pada Dinas Pertanian Kabupaten Pidie.

H6: Kedisiplinan berpengaruh positif terhadap kinerja pegawai pada Dinas Pertanian Kabupaten Pidie.

H7: Komitmen organisasi berpengaruh positif terhadap kinerja pegawai Pada Dinas Pertanian Kabupaten Pidie.

H8: Komitmen organisasi memediasi hubungan antara kepemimpinan dengan kinerja pegawai pada Dinas Pertanian Kabupaten Pidie.

\section{METODE PENELITIAN}

Variabel bebas dalam penelitian ini adalah kepemimpinan, motivasi dan kedisiplinan. Komitmen Oragnisasi sebagai variabel perantara, sedangkan variabel terikatnya adalah kinerja. Tipe penelitian adala pernyataan dengan menggunakan kuesioner sebagai alat untuk mengambil data. Instrumen penelitian menggunakan skala Linkert yang telah dimodifikasi 1-5. Populasi dalam penelitian ini adalah seluruh pegawai pada Pada Dinas Pertanian Kabupaten Pidie. Pengambilan sampel dengan metode sensus yaitu sebanyak 125 responden pegawai tetap. Teknik sampling sensus merupakan teknik penentuan sampel bila semua anggota populasi digunakan sebagai sampel (Sugiyono, 2009). Teknik analisis menggunakan Structural Equation Model (SEM) dengan menggunakan program 
komputer SPSS 16.0 dan Amos 21.0. Uji validitas instrumen menggunakan Confirmatory Faktor Analysis (CFA) masing- masing kontruk yaitu dengan melihat nilai Loading Factor masing-masing indikator dan didapat hasil setiap butir peryataan memiliki nilai $>0,6$. Adapun uji reabilitas dengan menggunakan rumus sebagai berikut:

$$
\text { Construct Reliability }=\frac{\left(\sum \text { std.loading }\right)^{2}}{\left(\sum \text { std.loading }\right)^{2}+\sum_{e i}}
$$

Sementara ekstrak varian dapat dihitung dengan rumus sebagai berikut:

$$
\text { Variance Extracted }=\frac{\sum \text { std.loading }{ }^{2}}{\sum \text { std.loading }+\sum_{e i}^{2}}
$$

\section{HASIL DAN PEMBAHASAN}

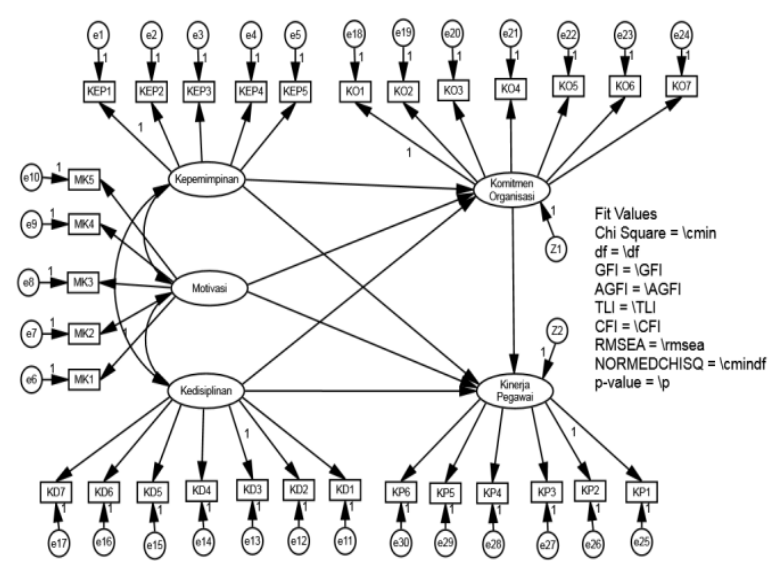

Gambar 3 Full Model

Uji full model SEM adalah uji yang dilakukan terhadap keseluruhan variabel eksogen maupun endogen yang telah digabungkan menjadi satu dan utuh melalui matrik varian dan kovarian dan model penuh itu disebut juga dengan model penelitian. Untuk mengetahui hasil pengolahan data yang telah dilakukan dengan menggunakan AMOS 21dapat dilihat pada Gambar 4 full model penelitian yang telah dilakukan modifikasi tersebut sebagai berikut: 


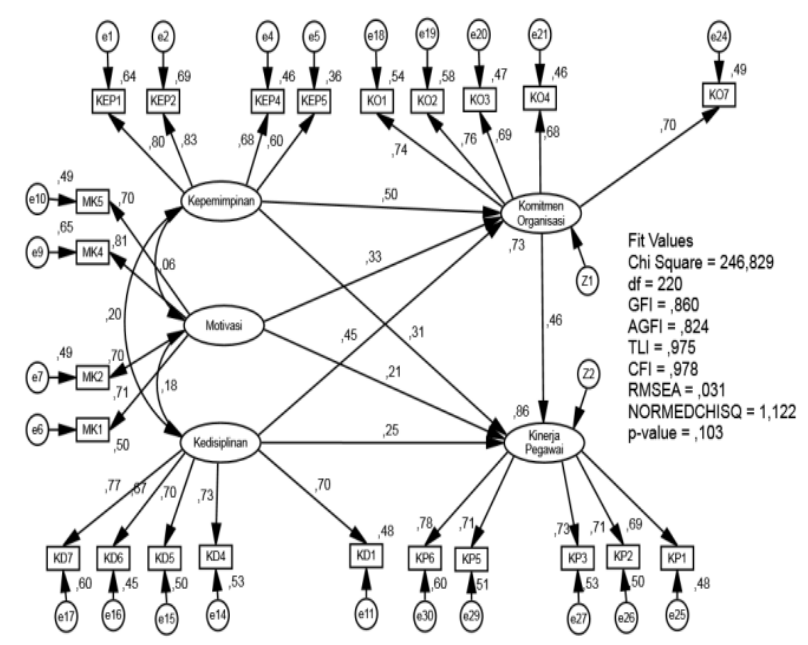

\section{Gambar 4 Full Model Setelah Modifikasi}

Untuk melihat hasil uji goodness of fit dapat dilihat pada Tabel 5.15:

Tabel 1

\section{Goodnessof Fit Indexs Full Model}

\begin{tabular}{lccc}
\hline Goodness of Fit Index & Cut-off Value & Hasil Analisis & $\begin{array}{c}\text { Evaluasi } \\
\text { Model }\end{array}$ \\
\hline$\chi^{2}$ Chi-Square Statistik & Diharapkan Kecil & 246,829 & Baik \\
Probability & $>0,05$ & 0.103 & Baikl \\
CMINDF & $\leq 2.00$ & 1.122 & Baik \\
GFI & $>0.90$ & 0.860 & Marginal \\
AGFI & $>0.90$ & 0,824 & Marginal \\
TLI & $>0.95$ & 0.975 & Baik \\
CFI & $\geq 0.95$ & 0.978 & Baik \\
RMSEA & $\leq 0.08$ & 0,031 & Baik \\
\hline
\end{tabular}

Hasil analisis goodness of fit menunjukkan keseluruhan evaluasi model telah memenuhi kriteria yang ditetapkan, kecuali nilai probability, GFI dan AGFI yang masih marginal, tetapi karena ukuran fil lainnya sudah baik maka model ini tidak perlu modifikasi dan sudah memenuhi syarat untuk pengujian hipotesis dalam penelitian ini.

Untuk melihat seberapa besar pengaruh variabel eksegen (kepemimpinan, motivasi, kedisiplinan) terhadap variabel intervening (komitmen organisasi) dan variabel endogen (kinerja pegawai) ditampilkan dalam Tabel 2: 
Tabel 2

Pengaruh Variabel Eksogen terhadap Variabel Endogen

\begin{tabular}{|c|c|c|c|c|c|c|}
\hline \multicolumn{2}{|c|}{ Laten Variabel } & Est. & $\begin{array}{l}\text { Std. } \\
\text { Est }\end{array}$ & S.E. & C.R. & $\mathrm{P}$ \\
\hline Kom. Organisasi & $<-$ Kepemimpinan & 422 & 501 & 080 & 5,292 & 0,001 \\
\hline Kom. Organisasi & $<-$ Motivasi &, 333 &, 335 & 087 & 3,811 & 0,001 \\
\hline Kom. Organisasi & <-. Kedisiplinan &, 444 & 449 &, 094 & 4,745 & 0,001 \\
\hline Kinerja_Pegawai & $<-$ Kepemimpinan &, 265 &, 312 & 094 & 2,809 & 0,005 \\
\hline Kinerja_Pegawai & $<$ Motivasi & 210 &, 210 & 091 & 2,322 & 0,020 \\
\hline Kinerja_Pegawai & <- Kedisiplinan & 247 &, 247 & 104 & 2,372 & 0,018 \\
\hline Kinerja_Pegawai & _- Kom. Organisasi & 460 & 456 & 169 & 2,713 & 0,007 \\
\hline
\end{tabular}

Berdasarkan hasil analisis data seperti yang ditampilkan pada Tabel 2 dapat dijelaskan bahwa ke semua variabel eksogen (kepemimpinan, motivasi, kedisiplinan) memiliki pengaruh langsung signifikan terhadap motivasi kerja dan kinerja pegawai, dan motivasi kerja berpengaruh signifikan terhadap kinerja pegawai.

\section{UJI EFEK MEDIASI}

Untuk melihat pengaruh efek mediasi, terlebih dahulu harus melihat seberapa besar pengaruh langsung (direct effect), tidak langsung (indirect effect) dan pengaruh keseluruhan (total effect). Berdasarkan pengujian yang dilakukan dengan menggunakan Amos. 21.0 diperoleh hasil seperti pada Tabel 3 .

\section{Tabel 3}

Standardized Direct, Indirect \& Total Effects

\begin{tabular}{lccccc}
\hline Hubungan & Kedisiplinan & Motivasi & Kepemimpinan & $\begin{array}{c}\text { Komitmen } \\
\text { Organisasi }\end{array}$ & $\begin{array}{c}\text { Kinerja } \\
\text { Pegaawai }\end{array}$ \\
\hline Direct Effects & & & & & \\
Kom. Organisasi & 0.449 & 0,335 & 0.501 & 0.000 & 0,000 \\
Kinerja Peganai & 0.247 & 0,210 & 0.312 & 0.456 & 0,000 \\
$\begin{array}{l}\text { Indirect Effects } \\
\text { Kom. Organisasi }\end{array}$ & - & - & - & & \\
Kinerja Peganai & 0.205 & 0.153 & 0.228 & 0.000 & 0.000 \\
Total Effects & & & & & \\
Kom. Organisasi & 0.449 & 0,335 & 0.501 & 0.000 & 0,000 \\
Kinerja Pegantai & 0.452 & 0,363 & 0.541 & 0.456 & 0,000 \\
\hline
\end{tabular}

Hasil pengujian efek memediasi (intervening) hubungan variabel kepemimpinan dengan variabel kinerja pegawai yang dimediasi oleh variabel komitmen oragnisasi dan ditampilkan dalam bentuk Gambar 5: 


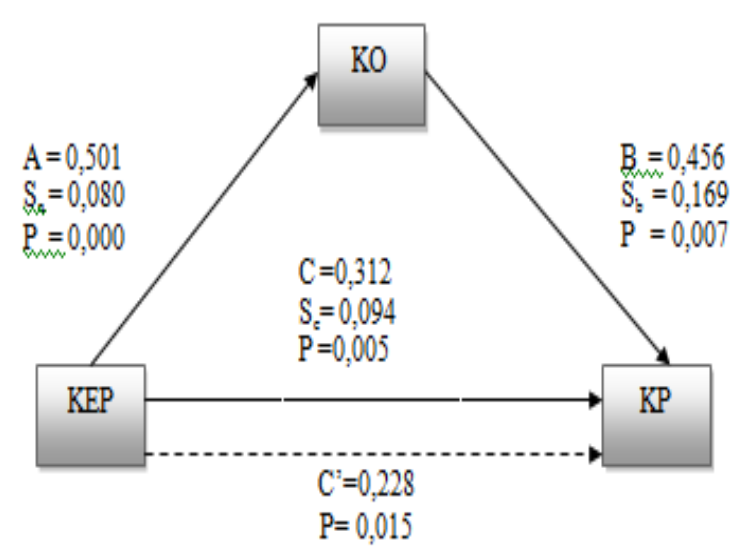

Gambar 5 dapat dijelaskan bahwa koefesien jalur A, jalur B dan jalur C, adalah signifikan dan nilai signifikansi jalur C' adalah tidak signifikan. Karena probabilitas jalur C' signifikan, sehingga dapat disimpulkan terjadi hubungan partial mediation atau dengan kata lain variabel komitmen organisasi memediasi secara partial mediation antara kepemimpinan dengan kinerja pegawai pada Dinas Kantor Dinas Pertanian Kabupaten Pidie.

Hasil pengujian efek memediasi (intervening) hubungan variabel kedisiplinan dengan variabel kinerja pegawai yang dimediasi oleh variabel komitmen organisasi dan ditampilkan dalam bentuk Gambar 6:

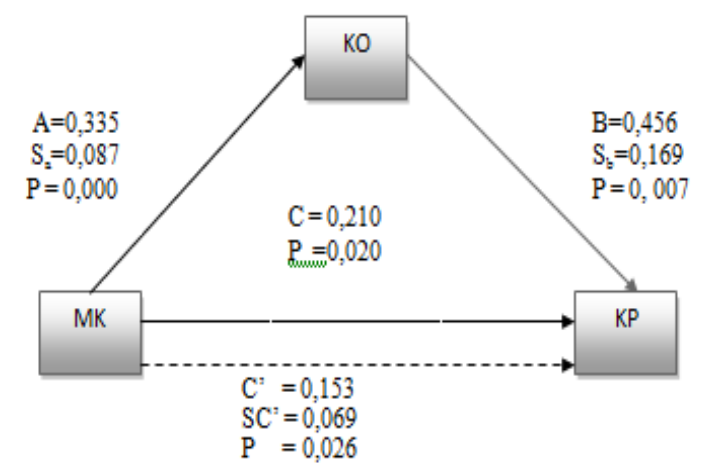

Gambar 6 dapat dijelaskan bahwa koefesien jalur A, jalur B dan jalur C, signifikan dan nilai signifikansi jalur C' adalah tidak signifikan. Karena probabilitas jalur C' signifikan, sehingga dapat disimpulkan terjadi hubungan partial mediation atau dengan kata lain variabel komitmen organisasi memediasi secara partial mediation antara variabel motivasi kerja dengan kinerja pegawai pada Dinas Kantor Dinas Pertanian Kabupaten Pidie.

Hasil pengujian efek memediasi (intervening) hubungan variabel kedisiplinan dengan variabel kinerja pegawai yang dimediasi oleh variabel komitmen organisasi dan ditampilkan dalam bentuk Gambar 7: 


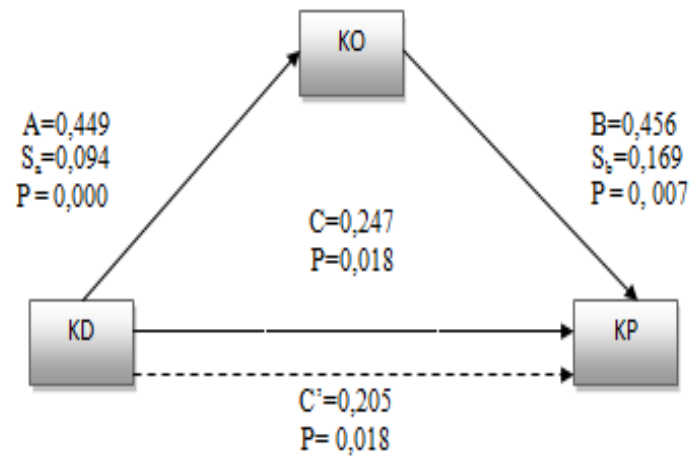

Gambar 7 dapat dijelaskan bahwa koefesien jalur A, jalur B dan jalur C, signifikan dan nilai signifikansi jalur C' adalah tidak signifikan. Karena probabilitas jalur C' signifikan, sehingga dapat disimpulkan terjadi hubungan partial mediation atau dengan kata lain variabel komitmen organisasi memediasi secara partial mediation antara variabel kedisiplinan dengan kinerja pegawai pada Dinas Kantor Dinas Pertanian Kabuten Pidie.

\section{Tabel 5}

Hasil Uji Hipotesis

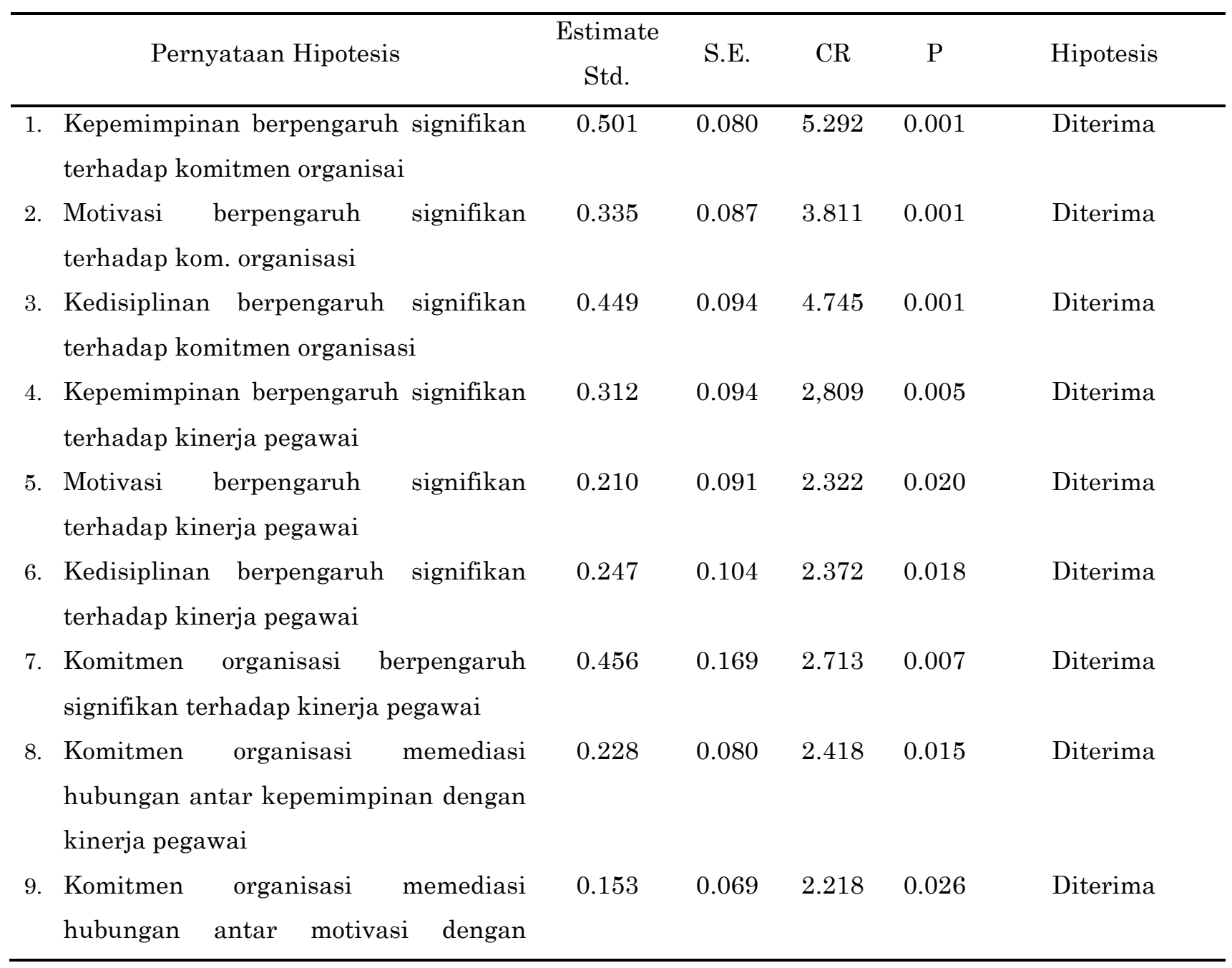


kinerja pegawai

10. Komitmen organisasi memedias

hubungan antar kedisiplinan dengan

kinerja pegawai

\section{IMPLIKASI}

Penelitian ini menghasilkan beberapa implikasi secara teoritis yaitu sebagai berikut :

1. Hasil penelitian ini juga menunjukkan bahwa variabel kepemimpinan, motivasi kerja, dan kedisiplinan memiliki arah pengaruh yang positif dan signifikan terhadap komitmen organisasi dengan kata lain kepemimpinan, motivasi kerja, dan kedisiplinan berdampak pada peningkatan kinerja karyawan, hal ini sejalan dengan kebanyakan hasil penelitian terdahulu yang menemukan adanya pengaruh yang positif dan signifikan variabel kepemimpinan, motivasi kerja, dan kedisiplinan terhadap komitmen organisasi sehingga penelitian ini telah memperkuat kerangka teoritis terkait pengaruh kepemimpinan, motivasi kerja, dan kedisiplinan terhadap kinerja pegawai.

2. Hasil penelitian ini juga menunjukkan bahwa variabel kepemimpinan, motivasi kerja, dan kedisiplinan memiliki arah pengaruh yang positif dan signifikan terhadap kinerja pegawai dengan kata lain kepemimpinan, motivasi kerja, dan kedisiplinan berdampak pada peningkatan kinerja pegawai, hal ini sejalan dengan kebanyakan hasil penelitian terdahulu yang menemukan adanya pengaruh yang positif dan signifikan variabel kepemimpinan, motivasi kerja, dan kedisiplinan terhadap kinerja pegawai sehingga penelitian ini telah memperkuat kerangka teoritis terkait pengaruh kepemimpinan, motivasi kerja, dan kedisiplinan kerja terhadap kinerja pegawai.

3. Berdasarkan hasil analisis data ditemukan bahwa variabel komitmen organisasi secara langsung memiliki arah pengaruh yang positif dan signifikan terhadap kinerja pegawai. Hasil penelitian ini sejalan dengan kebanyakan penelitian sebelumnya yang menyebutkan adanya pengaruh positif dan signifikan antara komitmen organisasi dengan kinerja pegawai sehingga kesamaan ini dapat menjadi landasan untuk memperkuat atau menambah kerangka teoritis berhubungan dengan pengaruh komitmen organisasi terhadap kinerja pegawai.

4. Berdasarkan hasil analisis data terdapat 3 (tiga) hasil penelitian yang sama, variabel komitmen organisasi memediasi secara mediasi parsial (partial mediation) hubungan antara kepemimpinan, motivasi kerja dan kedisiplinan terhadap kinerja pegawai.

5. Hasil penelitian dapat memberi kontribusi yang berharga bagi ilmu pengetahuan Karena dapat menambah penelitian sebelumnya yang masih dirasakan belum tersedia banyak, berhubungan dengan kedudukan variabel komitmen organisasi sebagai variabel intervening. 


\section{Implikasi secara praktis}

1. Hasil penelitian ini menunjukkan bahwa variabel kepemimpinan, motivasi kerja, dan kedisiplinan memiliki arah pengaruh yang positif dan signifikan terhadap kinerja pegawai Pada Dinas Pertanian Kabupaten Pidie, dengan kata lain kepemimpinan, motivasi kerja, dan kedisiplinan berdampak pada peningkatan kinerja pegawai Pada Dinas Pertanian Kabupaten Pidie.

2. Penelitian ini juga menemukan bahwa variabel kepemimpinan, motivasi kerja, dan kedisiplinan memiliki pengaruh yang positif dan signifikan terhadap komitmen organisasi artinya semakin baik kepemimpinan, motivasi kerja, dan kedisiplinan, maka semakin meningkat pula komitmen organisasi pegawai. Konsekuensi dari adanya beban kepemimpinan, motivasi kerja, dan kedisiplinan tentu untuk meningkatkan komitmen organisasi.

3. Hasil penelitian ini menunjukkan bahwa variabel komitmen organisasi memiliki arah pengaruh yang positif dan signifikan terhadap kinerja pegawai Pada Dinas Pertanian Kabupaten Pidie, dengan kata lain semakin tinggi komitmen organisasi tinggi akan berdampak kepada semakin tinggi juga kinerja pegawai Pada Dinas Pertanian Kabupaten Pidie. Temuan ini mengisyaratkan bahwa komitmen organisasi adalah hal yang harus dipenuhi oleh kepala dinas pencatatan sipil kepada pegawai untuk dapat meningkatkan kinerja pegawai.

4. Dalam penelitian ini ditemukan variabel komitmen organisasi dapat memediasi secara mediasi parsial (partial mediation) hubungan antara kepemimpinan, motivasi kerja, dan kedisiplinan terhadap kinerja pegawai. Implikasinya bagi Pada Dinas Pertanian Kabupaten Pidie yang ingin meningkatkan kinerja pegawai, antara lain dapat ditempuh dengan upaya peningkatkan komitmen organisasi pegawai.

\section{SIMPULAN}

Berdasarkan tujuan penelitian yang telah diuraikan sebelumnya, maka dapat dikemukakan beberapa kesimpulan penelitian sebagai berikut:

1. Kepemimpinan ber pengaruh positif dan signifikan terhadap komitmen organisasi pada Dinas Pertanian Kabupaten Pidie, Dengan kata lain pimpinan harus selalu berkomitmen memperhatikan bawahannya untuk terciptanya hasil kerja pegawai yang baik.

2. Motivasi berpengaruh positif secara signifikan terhadap komitmen organisasi pegawai Pada Dinas Pertanian Kabupaten Pidie. Dengan kata lain motivasi kerja bisa ditingkatkan kalau ada komitmen dari pimpinan dalam mendorong memperhatikan para bawahan untuk bekerja lebih baik.

3. Kedisiplinan berpengaruh positif dan signifikan terhadap Komitmen Organisasi pegawai pada Dinas Pertanian Kabupaten Pidie. Dengan kata kedisiplinan akan .tercapai dengan baik, bila ada aturan atau sanksi yang ketat terhadap bawahan yang tidak disiplin.

4. Kepemimpinan berpositif dan signifikan terhadap kinerja pegawai pada Dinas Pertanian Kabupaten Pidie. Dengan kata lain Pimpinan yang baik adalah yang bisa membimbing pegawainya lebih agar tercapai kinerja pegawai dengan baik. 
5. Motivasi berpengaruh positif dan signifikan terhadap kinerja pegawai pada Dinas Pertanian Kabupaten Pidie. Dengan kata lain kinerja akan tercapai dengan baik bila parapimpinan biasa mengarahkan dan mendorong para karyawan untuk lebih kreatif dan hasil kerjanya dinilai dengan pemberian reword.

6. Kedisiplinan berpengaruh positif dan signifikan terhadap kinerja pegawai pada Dinas Pertanian Kabupaten Pidie. Dengan kata lain Kinerja yang baik tercapai apabila kedisiplinan kerjanya dengan baik.

7. Komitmen Organisasi berpengaruh positif dan signifikan terhadap kinerja pagawai pada Dinas Pertanian Kabupaten Pidie. Dengan kata lain Kinerja pegawai tercapai bila ada komitmen dan loyalitas pimpinan dalam mengarahkan bawahan.

8. Komitmen Organisasi memediasi secara parsial hubungan kepemimpinan dengan kinerja pagawai pada Dinas Perttanian Kabupaten Pidie. Dengan katalain dengan komitmen yang tinggi maka secara langsung kinerja pegawai akan meningkat.

9. Komitmen Organisasi memediasi secara parsial hubungan motivasi dengan kinerja pegawai pada Dinas Pertanian Kabupaten Pidie, Dengan kata lain kinerja akan meningkat apabila motivasi kerja pegwai pun meningkat.

10. Komitmen Organisasi memediasi secara parsial hubungan kedisiplinan dengan kinerja pegawai pada Dinas Pertanian Kabupaten Pidie. Dengan kata lain Kedisiplinan sangat mempengaruhi kesungguhan pegawai dalam bekerja untuk mencapai kinerja yang baik.

\section{DAFTAR PUSTAKA}

Blanchard (2012). Nursing patients With acute Chest Pain: Practice Guided By The Prince Edward Island Conceptual Model for Nursing. Nurse Education In Practice. Emergency Room Nurse, Charlotetown, Prince Eduad Island, Canada B.School of Nursing, University of Prince Edward Island, Charlottetown, Prince Edward Island, Canada. Nurse education In Practice 10 (2012) 4851.

Fathoni, Abdurrahmat. (2006). Organisasi dan Manajemen Sumber Daya Manusia. Rineka Cipta, Jakarta.

Hasibuan S.P. (2005). Manajemen Sumber Daya Manusia, Edisi revisi. Bumi Aksara, Jakarta.

Hasibuan S.P. (2007). Manajemen Sumber Daya Manusia. PT. Bumi Aksara. Jakarta.

Hasibuan S.P. (2012), Manajemen Sumberdaya Manusia. Cetakan ke 16. P.T. Bumi Aksara. Jakarta.

Hersey dan Blanchand. (2012). Management of Organizational Behavior. Peeason Prencitice Hall, New Jersey.

Kuntjoro. (2009). Manajemen Sumberdaya Manusia. Erlangga, Jakarta. 
Mangkunegara. (2012). Manajemen Sumber Daya Manusia, Bandung.

Rivai, Veithzal. (2009). Manajemen Sumber Daya Manusia untuk Perusahaan dari Teori ke Praktik. Raja Grafindo Persada, Jakarta.

Siagian, Sondang P. (2010). Manajemen Sumber Daya Manusia. Bumi Aksara. Jakarta.

Sugiyono, (2009). Metode Penelitian Kuantitatif, Kualitatif dan R \& D.,: Bandung: Alfabeta.

Sulistiyani dan Rosidah. (2011). Manajemen Sumber Daya Manusia. Jakarta.

Suwanto. (2011). Manajemen SDM Dalam Organisasi Publik dan Bisnis. Alfabeta. Bandung.

Usman. (2006). Pengantar Statistika. Bumi Aksara, Jakarta. 